\author{
FEDERAL RESERVE BANK OF SAN FRANCISCO \\ WORKING PAPER SERIES
}

\title{
Mortgage Loan Securitization and Relative Loan Performance
}

\author{
John Krainer \\ Federal Reserve Bank of San Francisco \\ Elizabeth Laderman \\ Federal Reserve Bank of San Francisco
}

\begin{abstract}
August 2011
Working Paper 2009-22

http://www.frbsf.org/publications/economics/papers/2009/wp09-22bk.pdf
\end{abstract}

The views in this paper are solely the responsibility of the authors and should not be interpreted as reflecting the views of the Federal Reserve Bank of San Francisco or the Board of Governors of the Federal Reserve System. 


\title{
Mortgage Loan Securitization and Relative Loan Performance*
}

\author{
August 2011
}

\section{John Krainer and Elizabeth Laderman}

\begin{abstract}
We compare the ex ante observable risk characteristics, the default performance, and the pricing of securitized mortgage loans and mortgage loans retained by the original lender. We find that privately securitized fixed and adjustable-rate mortgages are riskier ex ante than lenderretained loans or loans securitized through the government sponsored agencies. We do not find any evidence of differential loan performance for privately securitized fixed-rate mortgages. However, we do find evidence that privately securitized adjustable-rate mortgages performed worse than retained mortgages, even after controlling for a large number of risk factors. Despite the higher measures of ex ante risk, the loan rates on privately securitized adjustable-rate mortgages were lower than for retained mortgages.
\end{abstract}

JEL Codes: G21, L11, D82. Key Words: Mortgage Lending, Securitization, Loan Quality, Asymmetric Information.

\footnotetext{
${ }^{*}$ Both authors are from the Federal Reserve Bank of San Francisco. The views expressed are those of the authors and not necessarily those of the Federal Reserve System. We thank Larry Cordell, Diana Hancock, Christopher James, Michael Koetter, Michael LaCour-Little, Shane Sherlund, and seminar participants at the Research Subcommittee of the Basel Committee on Banking Supervision, the Federal Reserve Bank of Atlanta, and the International AREUEA meetings. We would like to thank James Gillan and Armando Franco for excellent research assistance.
} 


\section{Introduction}

Mortgage markets have undergone a steady process of change over the period since the financial industry deregulation in the 1980s and up through the financial crisis. One of the more important developments over this period was the process of disintermediation that occurred through the growth of loan securitization, whereby many lenders chose to specialize in the production of mortgage loans, but not to maintain a lasting exposure to the loans after passing them on to investors. In light of the extremely high mortgage default rates observed after the U.S. housing market peaked in 2006, there has been a keen interest in whether there were links between the ways mortgage loans were funded and their eventual performance. In this paper, we compare the ex ante risk characteristics, the default performance, and the pricing of mortgage loans that were securitized through a private (i.e., nonagency) channel, versus loans that were securitized through the governmentsponsored agencies (GSEs) or retained in a lender's portfolio. To preview the results, we find that, on balance, lenders chose to privately securitize mortgages that appear to have been observably riskier than the loans they retained in their own portfolios. In terms of default experience, we find little evidence of differential loan performance for fixed-rate mortgages (FRMs). There appears to be some evidence that default rates were higher for privately securitized adjustable-rate mortgages (ARMs), although we maintain, however, that other observable risk factors better explain the patterns of mortgage default in our data. We cannot attribute the differential loan performance of the ARMs to heterogeneity that was unobservable to us but observable to lenders and therefore would have been expected to be priced, given some positive ex ante probability of retention.

The literature has identified numerous reasons for loan securitizations and for mortgage loan securitizations, in particular. These reasons, with their varying theoretical implications for the relative riskiness of securitized versus retained loans, motivate our empirical investigation of the ex ante risk characteristics and ex post performance of these loan categories. In addition, they guide our selection of control variables for our securitization regressions and provide an informal framework within which to discuss the empirical correlates of securitization.

Perhaps the simplest motive for lenders to securitize is the desire to generate fee income and maintain the funding flexibility needed to increase lending or manage the lender's leverage position. 
In the so-called "originate-to-distribute" model, lenders effectively fund a portion of their operations through the capital markets, selling their mortgages to investors shortly after origination (see Pavel and Phillis (1987) and Karaoglu (2005)). To the extent that mortgage credit risk depends closely on house prices, loan securitization also may help locally or regionally tied lenders offload or diversify away geographically-based risks. Note that neither of these aforementioned securitization motives have an obvious implication for loan performance, although reputational concerns may motivate lenders who want to reliably generate fee income or diversify away geographically-based risks to securitize their less risky loans.

Another possibility is that lenders may want to securitize mortgage loans in order to reduce their regulatory capital ratios. This motive would be particularly relevant for regulated commercial banks. Throughout most of our sample period (2000-2007), regulatory capital rules stipulated a one-size-fits-all capital charge for mortgage loans on a bank's books. If those capital charges were perceived by lenders to be too high, then, all else held constant, banks would have an incentive to securitize their lower-risk mortgages while retaining the higher-risk loans for which the regulatory capital charge is closer to optimal. ${ }^{1}$

Yet another reason for loan securitization comes from the observation that there are significant informational asymmetries present throughout the lending and securitization process. Over the course of the loan application and screening process, lenders can potentially collect valuable information about borrower default risk that is not necessarily passed along to investors if the mortgages are securitized. Lenders may exploit this informational advantage and pass on "lemons" to investors while retaining the safer loans in their own portfolio. (See, for example, Carey (1998), with a focus on corporate bonds.) The asymmetric information story of securitization, then, yields a risk implication that is the opposite of the likely risk implications of the fee income, diversification, or regulatory capital management stories. In a recent paper, Elul (2011) finds some evidence of differential loan performance consistent with the asymmetric information story in certain mortgage product types.

Securitization may also undermine a lender's incentives to screen borrowers, as these activities

\footnotetext{
${ }^{1}$ See, for example, Jones (2004), Dionne and Harchaoui (2003), Minton, Sanders, and Strahan (2004), Nolan (2005), and Ambrose, LaCour-Little, and Sanders (2003).
} 
are costly, and lenders may not directly benefit from heightened screening of loans that likely will be securitized. The screening story has been investigated in a recent paper by Keys, Mukherjee, Seru, and Vig (2010), wherein the authors make use of an industry rule-of-thumb that loans to borrowers with FICO credit scores just below 620 are more difficult to securitize than loans with scores just above this threshold. Given this discrete jump in the probability that the loan can be sold, the authors reason that lenders have a stronger incentive to produce "soft" information in order to better discriminate between good and bad credit risks for loans to borrowers with FICO scores below 620 than above 620 . In turn, the authors find that, despite the normally negative correlation between FICO scores and credit risk, delinquency rates are lower for borrowers just below the 620 FICO cutoff for a large sample of securitized mortgages. The authors contend that this reflects lenders' stronger incentive to produce information for the less highly securitized group. If, indeed, lenders do take advantage of private information to pass along lemons to private investors, then we should see higher default rates for privately securitized mortgages, after controlling for risk characteristics that investors should have been able to observe.

In this paper, we examine three basic issues related to securitization. First, we use a large loanlevel data set to explore the factors that are associated with securitization. Second, we compare the default performance of securitized versus retained mortgage loans, both unconditionally and conditioned on the same risk factors that we explore in connection with the securitization decision, as well as important control variables. Third, we compare the conditional pricing of securitized mortgages and mortgages retained in the portfolio to see whether we can detect any differential pricing of loans that eventually end up in securitizations.

To answer these questions we use a very rich data set of California mortgages that allows us to gain insight into mortgage terms, borrower characteristics, and measures of the amount of lender competition in the market. California is an excellent laboratory for investigating these questions. California has a large and highly diverse economy and is characterized by equally diverse local real estate markets. California had some of the best and worst-performing markets (in terms of mortgage default rates) in the country. In addition, the level of house prices in California is quite a 
bit higher than for the overall country. ${ }^{2}$ As such, the conforming loan limits set by the GSEs tend to be binding for a larger segment of the California market than for other states. Thus, innovations that made mortgage lending through the private securitization process more attractive likely had a relatively large impact on the origination of mortgage debt in California.

Our paper differs from that of Elul (2011) in several respects. First and most important, we examine the relative pricing of securitized mortgages. Even if securitized mortgages default at a higher rate than retained mortgages, lenders would not appear to be knowingly exploiting asymmetric information to offload risk to investors unless it is also true, given some positive ex ante probability of retention, that such loans carry higher interest rates. In this paper, we use the interest rate on the mortgage as a rough proxy for investors' returns. We test whether, for example, the higher default rate for securitized than for retained ARMs is reflected in a higher loan interest rate. We find that it is not-the interest rate is, in fact, lower-and we argue that this result is not consistent with lenders knowingly exploiting asymmetric information or engaging in differential screening. Second, we estimate an empirical model of the securitization decision as a function of observable risk factors. Elul (2011) does not examine the securitization decision. We find that, ex ante, securitized mortgages look riskier than retained mortgages. This result serves as a robustness check on our default results and their interpretation. For example, we find that, conditional on observable risk factors, securitized ARMs default at a higher rate than retained ARMs, suggesting that lenders offload risk to investors. If we had found that, ex ante, securitized ARMs look safer than retained, we would be more likely to question our default results and interpretation, for they would imply an implausible ability of lenders to privately identify and profitably sell more risky safe looking mortgages than risky risky looking mortgages. Third, we include measures of prepayment risk in our default regressions. Finally, we emphasize that, although securitized ARMs default at a higher rate than retained ARMs, factors other than securitization are much more important in explaining their relative performance.

The rest of the paper is organized as follows. In Section 2, we offer a brief overview of the private-label securitization process. In Section 3, we describe the data used in the empirical analysis.

\footnotetext{
${ }^{2}$ According to the California Association of Realtors the median single-family house price in California in 2007 was $\$ 476,000$, above the prevailing conforming loan limit of $\$ 417,000$ at that time.
} 
Section 6 presents the results from our securitization regressions. Section 5 contains the analysis of the comparative default experience of securitized and nonsecuritized mortgages. Section 6 contains price regressions. Section 7 concludes.

\section{The private-label securitization process}

Securitization is the process by which originated loans are combined and repackaged for sale to capital market investors. There are two different channels through which residential mortgages are securitized in the United States. Agency securitizations are issued through the government sponsored enterprises (GSEs) such as Fannie Mae, Freddie Mac, and Ginnie Mae. ${ }^{3}$ Nonagency securitizations, or private-label securitizations, are issued by entities other than the GSEs, usually large banks or Wall Street firms. The private-label securitization process results in the transformation of whole mortgage loans into publicly-traded securities which are registered through the Securities and Exchange Commission.

The main difference between agency and private-label securitizations is in the credit risk of the underlying mortgages. The GSEs fully guarantee the timely repayment of principal and interest of their securitizations. Because the GSEs have traditionally been viewed by market participants as enjoying the backing of the U.S. government, strict criteria were put in place in an attempt to limit the amount of credit risk taken on by the GSEs. These criteria included caps on the size of the individual mortgages that the GSEs can buy (the conforming loan limits), as well as other underwriting guidelines applied to the amount of borrower leverage in place and the ratio of borrowers' scheduled monthly debt repayment to income. In essence, the nonagency market grew up to absorb the demand for mortgages that were "nonconforming", either in terms of their size or because of some violation of one or several underwriting criteria. According to Bruskin, Sanders, and Sykes (1999), the first private-label mortgage security was issued by Bank of America in 1977. But the real growth in the market took place in the 2000s. According to the Federal Reserve's Flow of Funds data, private securitizations accounted for about $14 \%$ of all residential mortgage securitizations in 2000.Q1. By 2006, the private-label share had risen to $36 \%$.

\footnotetext{
${ }^{3}$ We exclude mortgages securitized through Ginnie Mae from our data set.
} 
At a conceptual level, the process of privately securitizing residential mortgages is relatively simple; lenders extend mortgage credit to borrowers, and then sell the loans so that they may be repackaged and sold on to investors. In practice, however, specialization has led to the inclusion of a large number of economic agents that are party to the securitization process. Figure 1 contains a general schematic of the various parties involved in a mortgage transaction that eventually ends up in a securitization. In brief, originators extend financing to borrowers, or mortgagors. If the originator is a depository institution such as a commercial bank, then it is possible initially to finance the loan through deposits. Alternatively, the originator may finance its lending through short-term loans from a warehouse lender. After origination, an arranger, or sponsor, buys the mortgage loans from the originator and proceeds to sell the mortgages to a bankruptcy-remote trust. The arranger then packages the mortgages into securities, obtains a rating for the securities by one of the major credit rating agencies, and then sells the securities to outside investors. As borrowers make interest and principal payments, a servicer passes the cash flows on to investors in accordance with the terms laid out in the securities prospectus. ${ }^{4}$

Ashcraft and Schuermann (2008) point out that the parties in each of the interactions listed above have potentially different information about the quality of the underlying mortgages. ${ }^{5}$ Originators perform the original underwriting on the loans and (presumably) verify the borrower's income, employment history, credit score, and other information, to the extent that verification is required by the arrangers. Arrangers issue underwriting guidelines to the originators stating parameters needed to be satisfied for any loan purchase. Arrangers do not typically "re-underwrite" the loans in the pool. Instead, arrangers are protected through representations and warranties made by the originator that the mortgages were not originated in violation of any consumer protection laws, that the mortgages were not fraudulently misrepresented, or that the mortgagors were not

\footnotetext{
${ }^{4}$ For example, a "plain-vanilla" security might stipulate that an investor is entitled to a pro-rata share of the cash flows generated by the pool of mortgages owned by the trust. Alternatively, the claims on the assets may be structured, in which case investors in different securities have different priority to the cash flows on the underlying mortgages.

${ }^{5}$ Losses due to borrower default may not necessarily be borne by investors in the private-label securitizations. The arrangers may have "over-collateralized" the structure by setting the par value of the securities below the face value of the underlying mortgages, thus building in some buffer for losses. Alternatively, the arrangers may have purchased some limited insurance to cover losses. Either way, the focus here is on the different information produced by the originator relative to the arrangers and, in turn, to the investors.
} 
Figure 1: The private-label securitization process

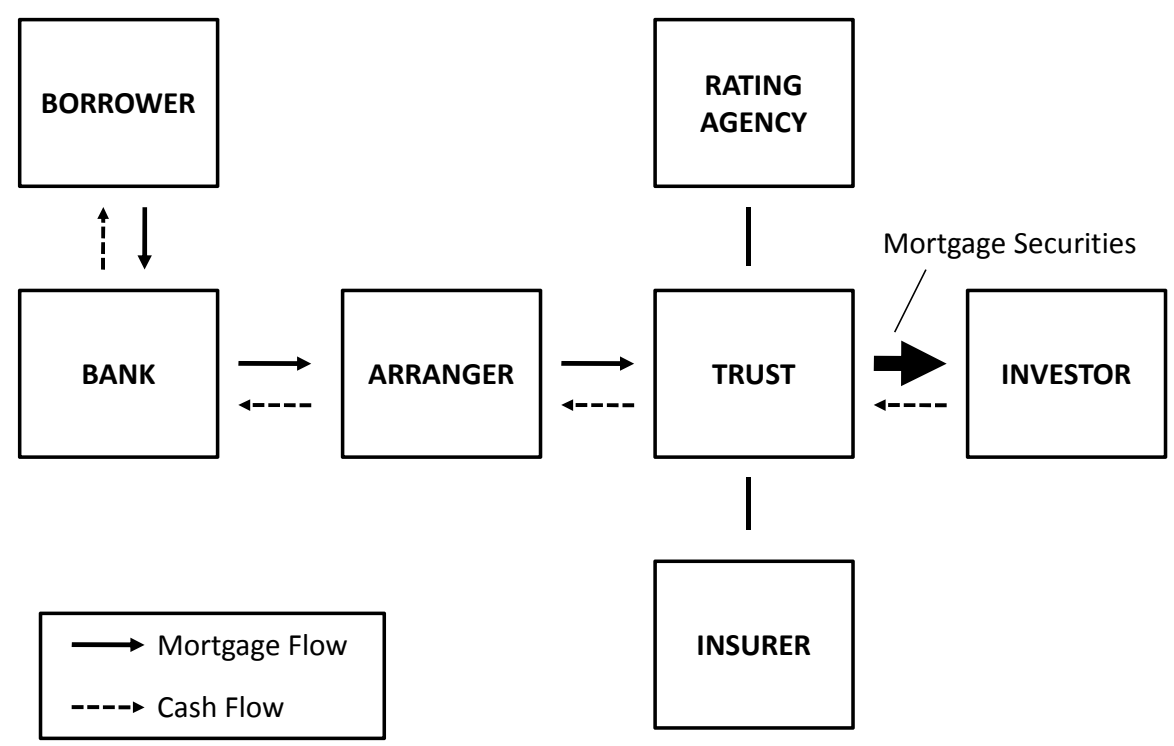

already in default. Originators are under obligation to buy back loans found to be in breach of the representations and warranties. Of course, the representations and warranties provide a solution to this potential agency problem only insofar as the originator is in good enough financial condition to repurchase the loans.

The potential information asymmetries between the originators and the eventual investors help motivate our empirical investigation of the characteristics and default rates of privately securitized mortgages relative to those of retained mortgages. In particular, we will investigate the correlation between ex ante observable risk factors and the private securitization decision. In addition, we will examine the degree to which these risk factors can account for any differential between realized default rates and therefore the degree to which asymmetric information may play a role.

\section{Data}

Our data set consists of information on the characteristics, terms, and eventual performance of more than 1.6 million first-lien conventional mortgage loans originated between January 1, 2000 
and December 31, 2007, for properties in California. The data come from LPS Applied Analytics, which collects data from the major mortgage servicers. ${ }^{6}$

Importantly, LPS reports the "investor type" for each loan in its database as the loan moves through time. Thus, we are able to discern between loans that were sold to the GSEs (Fannie Mae and Freddie Mac), sold to investors through a private securitization, or retained on the originating institution's balance sheet. In practice, the identity of the investor can change over time. In the first few months of a loan's life, for example, the investor is typically identified as the originator, which retains ownership of the loan throughout the "warehousing" period. The investor identity then changes as these loans leave the balance sheet of the originator and proceed through the securitization process. Investor type can change even after the initial warehousing period if, for example, a loan is securitized and then bought back (or returned) by the originator. The convention used in this paper is to make a once-and-for-all assignment of the investor type, which is based on the investor identity six months after the loan origination.

The loan-level data in our sample allow us to identify the location of the property backing the mortgage and thereby to include a measure of lending competition for the market in which the house is located. Thus, in some of the the default and pricing specifications, we include a simple concentration measure, the Herfindahl-Hirschman Index (HHI), based on bank deposit data for the metropolitan area in which the property resides. We also include the last two years of house price appreciation in the zip code of the property in several of our specifications. The zip code-level data are from the Home Value Indices constructed by Zillow. Given that we see a strong persistence of house prices in our data, we include this variable to account for possible lender optimism about house price appreciation at a very local level.

About $82 \%$ of the sample consists of loans that were securitized in some way-either privately or through the GSEs (see Table 1). In aggregate, securitization decreased over most of the sample period (see Figure 2). However, this trend masks large shifts that took place in the means by which securitization was achieved. In 2000, only about $20 \%$ of California mortgages were securitized privately. By 2005, the private securitization rate had almost doubled. This growth in private

\footnotetext{
${ }^{6}$ In LPS's marketing literature, they claim that their participating servicers account for about $60 \%$ of the entire mortgage market.
} 
securitization coincided with rapid house price appreciation in California.

Table 1: Summary Statistics

\begin{tabular}{|c|c|c|c|c|c|c|}
\hline & \multicolumn{2}{|c|}{ Full Sample } & \multicolumn{2}{|c|}{2002 Originations } & \multicolumn{2}{|c|}{2006 Originations } \\
\hline & mean & std. dev. & mean & std. dev. & mean & std. dev. \\
\hline Securitized & .817 & & .906 & & .772 & \\
\hline Privately securitized & .311 & & .258 & & .383 & \\
\hline Loan Purpose: Refinance & .762 & & .859 & & .690 & \\
\hline Jumbo & .278 & & .171 & & .339 & \\
\hline ARM & .387 & & .211 & & .568 & \\
\hline Option ARM & .231 & & .124 & & .374 & \\
\hline Loan amount & $\$ 331,713$ & $\$ 273,734$ & $\$ 237,359$ & $\$ 188,625$ & $\$ 423,547$ & $\$ 333,207$ \\
\hline Loan-to-value & .618 & .187 & .575 & .189 & .646 & .182 \\
\hline Subprime & .034 & & .001 & & .095 & \\
\hline FICO & 723 & 56 & 734 & 53 & 715 & 58 \\
\hline Low documentation & .389 & & .306 & & .510 & \\
\hline Local HHI (deposits) & 1,071 & 276 & 1,079 & 263 & 1,027 & 299 \\
\hline 2-yr House price apprec. & .345 & .21 & .268 & .136 & .317 & .200 \\
\hline Delinquent $60+$ days & .057 & & .016 & & .147 & \\
\hline Observations & $1,643,082$ & & 94,292 & & 207,041 & \\
\hline
\end{tabular}

In Table 1, we highlight additional changes, focusing first on 2002 and then 2006, when house prices peaked in California. For example, with house prices increasing faster than the the GSE conforming loan limits over this period, we see the share of jumbo loans (larger than the conforming loan limit) increasing from about $17 \%$ in 2002 to $34 \%$ in 2006 . A change in borrower preferences for ARMs versus fixed-rate mortgages apparently also accompanied this pressure on home affordability. Indeed, even option ARMs, or ARMs where borrowers are able to negatively amortize their mortgages for a set period of time, gained in popularity as the housing boom progressed.

We also see some evidence of a decline in underwriting standards. For example, LTVs moved up modestly over the sample period. The subprime share of total originations climbed from about $1 \%$ to a peak of $10 \%$ in 2006 . The incidence of less-than-full documentation of borrower income and assets increased over the period as well. Other sample statistics as well are presented in Table 1 .

In Table 2, we recast the sample summary statistics in order to show how the key variables in the data vary across investor type. Obviously, there are large differences between the mortgages 
Figure 2: Securitization by Year

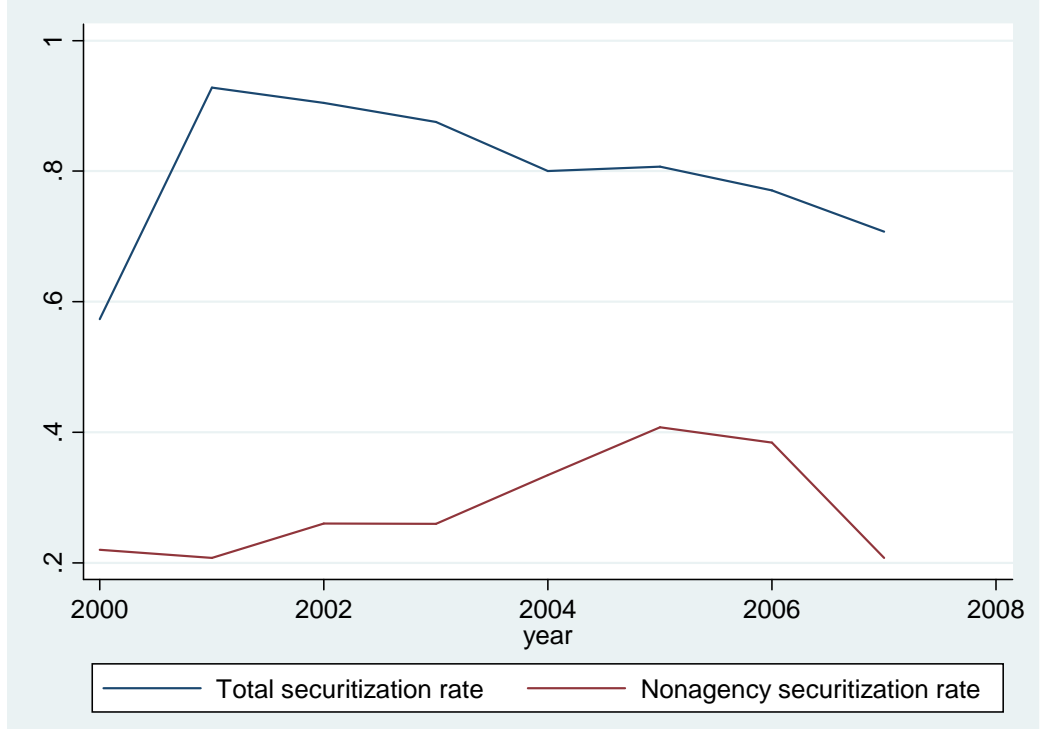

sold to the GSEs on the one hand and mortgages either retained by lenders or securitized through the private-label channel on the other hand. It is perhaps surprising to see that the GSEs hold any jumbo mortgages, or mortgages with nonconforming features such as option ARMs. We can conjecture that these mortgages were not part of a GSE-securitization, but rather were originally privately securitized and then purchased by the GSEs and held in their portfolios.

The other interesting feature of Table 2 is the similarity of many of the mortgage characteristics across retained and privately securitized mortgages. In terms of the major risk factors thought to contribute to default-LTV, FICO score, documentation status-it is not obvious from these statistics that lenders systematically withheld safe mortgages from the market for retention in their portfolios. The one exception is the case of the subprime indicator. Clearly, the privatelabel securitization channel was the primary way in which subprime mortgage loans were financed in California over this time period. And, as we'll see below, there are statistically significant differences at the margins even in terms of the other risk factors between privately securitized and retained mortgages. 
Table 2: Risk and Default Characteristics of Securitized vs. Retained Loans

\begin{tabular}{lcccccc}
\hline & \multicolumn{2}{c}{ GSE securitized } & Private securitized & \multicolumn{2}{c}{ Retained } \\
& mean & std. dev. & mean & std. dev. & mean & st. dev \\
\hline Loan Purpose: Refinance & .848 & & .690 & & .762 & \\
Jumbo & .011 & & .545 & & .566 & \\
ARM & .152 & & .546 & & .769 & \\
Option ARM & .067 & & .345 & & .493 & \\
Loan amount & $\$ 217,610$ & $\$ 89,926$ & $\$ 420,163$ & $\$ 273,487$ & $\$ 497,016$ & $\$ 426,736$ \\
Loan-to-value & .569 & .192 & .661 & .169 & .680 & .167 \\
Subprime & 0.0 & & .092 & & .029 & \\
FICO & 728 & 54 & 718 & 57 & 716 & 57 \\
Low/no documentation & .325 & & .423 & & .511 & \\
Local HHI (deposits) & 1,067 & 281 & 1,074 & 271 & 1,076 & 268 \\
2-yr House price apprec. & .351 & .19 & .359 & .209 & .306 & .218 \\
Delinquent 60+ days & .026 & & .100 & & .069 & \\
Observations & 831,450 & & 511,287 & & 300,345 & \\
\hline
\end{tabular}

\section{Determinants of securitization}

In this section we estimate multivariate logit regressions of the propensity of lenders to securitize mortgages. Our focus in this paper is on the relative risk consequences of the lender's decision regarding whether or not to securitize through a private-label transaction. However, recognizing all three possibilities for the allocation of mortgages-retention, private securitization, or agency securitization-we estimate the following regressions in a competing risks framework.

The multivariate analysis allows us to control for various factors in order to provide a richer and clearer picture of the correlates of the securitization decision. To handle outliers, we winsorize all of the continuous variables in the regressions. We also include a complete set of time-MSA interaction dummies in each specification, and we cluster the standard errors by MSA. We include both purchase loans and refinance loans. ${ }^{7}$

The specifications in Table 3, pertaining to private securitizations, and Table 4 , pertaining to agency securitizations, are organized by grouping the explanatory variables into types. Variables of the first two types, loan characteristics (Jumbo, ARM, Option ARM, Loan-to-value), and borrower characteristics (Subprime, FICO, Low/no documentation), measure the riskiness of the loan. Variables of the third type, bank characteristics (equity capital-to-asset ratio categories and nonper-

\footnotetext{
${ }^{7}$ We estimated the models separately for purchases and refinances, and the results were very similar.
} 
forming loan ratio categories), measure the propensity of the lender to securitize due to a constraint on portfolio lending by way of regulatory minima on capital-to-asset ratios. ${ }^{8}$ The remaining variable, Past two-year house price appreciation, also measures riskiness, but at a market level. During the period under study, areas with rapid house price appreciation tended to subsequently witness rapid depreciation. The reported coefficients are marginal effects. For continuous variables (Loanto-value, FICO, and house price appreciation), the reported marginal effects measure the change in the probability of securitization due to a one standard deviation change in the explanatory variable, evaluated at the means of all of the explanatory variables. For dummy variables (Jumbo, ARM, option ARM, Subprime, Low/no documentation, equity ratio categories, and nonperforming loan ratio categories), the marginal effects measure the change in the probability of securitization due to a change in the dummy variable from zero to one.

Positive correlations between higher risk and private securitization pervade the marginal effects seen in Table 3. The risk-based specifications, columns (i), (ii), and(iv), indicate that a mortgage is more likely to be privately securitized, as opposed to retained, if it is jumbo, has an ARM or option ARM interest rate structure, or has little or no documentation. In addition, LTV is positively correlated with private securitization.

As expected, banks with equity ratios lower than the 75th percentile are more likely to privately securitize their mortgages, as are banks with nonperforming loan ratios above the 75 th percentile.

In general, the regression results from the separate category specifications are robust to the inclusion of additional variables. Only the low documentation variable has a statistically significant marginal effect in one of the more parsimonious specifications (positive in column (ii)) that is the opposite of a statistically significant effect in a combined specification (negative in column (v)).

\footnotetext{
${ }^{8}$ We constructed the equity ratio and nonperforming loan ratio variables as follows. We calculated the means of each of these variables for each lender, with the mean taken over that lender's closing dates. The low, low-mid, and high-mid equity ratio and nonperforming loan ratio variables in the regressions are dummies indicating the positions in the sample distributions of these means of the actual values of the lender's equity ratio and nonperforming loan ratio at the time of loan closing-below the 25 th percentile, between the 25 th and 50 th percentiles, and between the 50 th and 75 th percentiles, respectively. Thus, the coefficients on these variables indicate the marginal effect on the probability of securitization of moving from a value of the corresponding variable that is above the 75 th percentile to a lower value. Note that it is not true that, for example, 25 percent of the loans in the sample have a value of 1 for "low equity ratio." In fact, only about 11 percent do. This is because banks with higher mean equity ratios tend to originate more mortgages than banks with lower mean equity ratios and/or banks tend to originate more mortgages when their equity ratios are high relative to their own equity ratios at other times.
} 
And even this inconsistency is mild, in that the statistical significance of the negative marginal effect is weak and does not persist in the last two, more general specifications. In the last two specifications, columns (vi) and (vii), the marginal effect of the low documentation variable is not statistically significant at all. ${ }^{9}$ One other variable, ARM, also has a statistically significant marginal effect in its category regression (column (i)), but not in the full specification. Perhaps, once we control for other factors, the attractiveness of retaining ARMs due to their short durations, which facilitate a better balance with short-term liabilities, increases in dominance.

Except for low documentation and ARM, marginal effects that appeared as statistically significant in the category regressions remain so in each of the combined specifications in which the variable appears. Two variables, FICO and house price appreciation, do not show statistically significant marginal effects in their respective category regressions (columns (ii) and (iv)). However, their marginal effects appear as highly statistically significant in all other specifications that include them. The positive coefficients on FICO indicate that privately securitized mortgages tended to have higher borrower credit scores than retained mortgages. This turns out to be a consequence of the mix of FICO scores in the privately securitized loan pools. In effect, private market investors were willing to hold two kinds of mortgages that were being produced in ample quantity over this time period: low FICO score subprime loans and higher FICO score alt-A loans where borrower attributes were better (safer) but some other risk factor rendered the loan nonconforming. ${ }^{10}$ The positive coefficient on house price appreciation in column (vii) indicates the expected correlation with risk.

In summary, what emerges from the models of the private securitization choice is a general picture of lenders selling off loans that appear to be marginally riskier than the loans that are retained. This differential risk in the loans will be important when evaluating the eventual performance of the mortgages.

Although our focus is on the private securitization decision, we also present the results of the multivariate logit regression for agency securitizations, in Table 4 . Here, the general picture is one

\footnotetext{
${ }^{9}$ The appearance of equal marginal effects and standard errors for low documentation in columns (vi) and (vii), accompanied by differing significance levels, is due to rounding.

${ }^{10}$ For example, in California at this time, many alt-A loans were labeled thus because the loan amounts exceeded the GSE's conforming loan limits, or sometimes the borrower debt-to-income or LTV ratios were considered too high.
} 
of lenders selling off loans that appear to be marginally safer than the loans that are retained. Except for FICO, the signs of the marginal effects for each of the variables in the full specification in Table 4 are the opposite of those in the full specification in Table 3 . 


\section{Determinants of Mortgage Delinquencies}

While the results of the previous section provide insights into the relationships between mortgage securitization and loan, borrower, market, and lender characteristics, they have unclear implications for the performance of securitized relative to retained loans. Privately securitized mortgages appear to be riskier in observable ways: the borrowers associated with the securitized mortgages are more likely to be subprime borrowers and tend to have higher LTVs. The strategy employed in the analysis of mortgage default below is twofold. First, we would like to identify the key determinants of mortgage default in our sample. Second, we would like to control for observable risk factors as best we can so as to focus on the relative performance of the securitized and retained mortgages. On this front, the biggest challenge is to properly control for changes in the value of the underlying collateral. Common sense and theory all suggest a role for house price changes as key determinants behind the default decision. However, we observe the value of the house only at the time of the loan origination. Thereafter, we can only estimate the current LTV by applying the appreciation (or depreciation) observed in a local house price index to the original appraised value of the house and divide by the remaining loan balance. If a local housing market is fairly homogeneous, then our index-based estimates of home values will be reliable. To attempt to control for market-specific heterogeneity, we include Metropolitan Statistical Area (MSA) fixed effects in all of our empirical specifications.

Unconditionally, privately-securitized mortgages do appear to have higher delinquency rates than both retained mortgages and mortgages that end up in agency securitizations. As seen in Table 2, the delinquency rate on privately securitized loans in our sample, at about $8 \%$, is notably higher than the $6 \%$ default rate for retained loans. Kaplan-Meier estimates of the survival function for loans with different investor types show that the privately securitized mortgages defaulted earlier, on average, than retained loans or loans securitized through the GSEs (see Figure 3).

To investigate the performance of the loans in our sample more carefully we follow the literature and model the default event with a competing risks hazard model. In this setting, mortgage histories can terminate in two competing ways. The mortgage can fall into default status, which we define to be the event that a borrower becomes more than 60 days past due on his or her mortgage payment. 
Table 3: Multinomial logit models of securitization-privately securitized

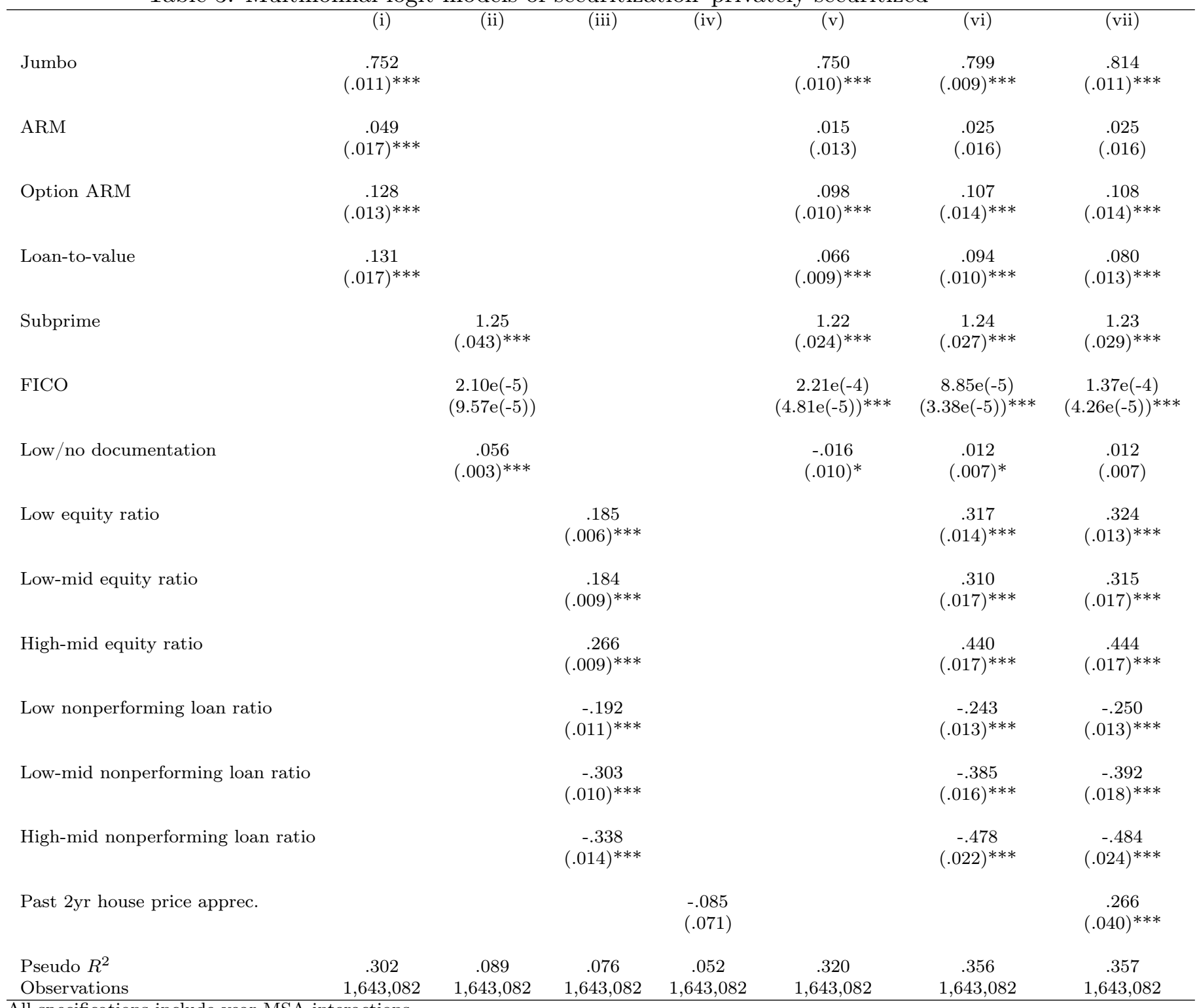

All specifications include year-MSA interactions.

Coefficient estimates are marginal effects, at sample means.

Standard errors clustered by MSA.

Significant at: .01(***), .05(**),.1(*). 
Table 4: Multinomial logit models of securitization-agency securitized

\begin{tabular}{|c|c|c|c|c|c|c|c|}
\hline & (i) & (ii) & (iii) & (iv) & $(\mathrm{v})$ & (vi) & (vii) \\
\hline Jumbo & $\begin{array}{c}-1.02 \\
(.010)^{* * *}\end{array}$ & & & & $\begin{array}{c}-.999 \\
(.009)^{* * *}\end{array}$ & $\begin{array}{c}-1.05 \\
(.010)^{* * *}\end{array}$ & $\begin{array}{c}-.1 .07 \\
(.011)^{* * *}\end{array}$ \\
\hline $\mathrm{ARM}$ & $\begin{array}{c}-.282 \\
(.012)^{* * *}\end{array}$ & & & & $\begin{array}{c}-.255 \\
(.009)^{* * *}\end{array}$ & $\begin{array}{c}-.260 \\
(.011)^{* * *}\end{array}$ & $\begin{array}{c}-.261 \\
(.011)^{* * *}\end{array}$ \\
\hline Option ARM & $\begin{array}{c}-.187 \\
(.025)^{* * *}\end{array}$ & & & & $\begin{array}{c}-.153 \\
(.025)^{* * *}\end{array}$ & $\begin{array}{c}-.192 \\
(.021)^{* * *}\end{array}$ & $\begin{array}{c}-.192 \\
(.021)^{* * *}\end{array}$ \\
\hline Loan-to-value & $\begin{array}{c}-.245 \\
(.032)^{* * *}\end{array}$ & & & & $\begin{array}{c}-.188 \\
(.026)^{* * *}\end{array}$ & $\begin{array}{c}-.220 \\
(.020)^{* * *}\end{array}$ & $\begin{array}{c}-.206 \\
(.023)^{* * *}\end{array}$ \\
\hline Subprime & & $\begin{array}{c}-1.63 \\
(.080)^{* * *}\end{array}$ & & & $\begin{array}{c}-1.39 \\
(.055)^{* * *}\end{array}$ & $\begin{array}{c}-1.42 \\
(.057)^{* * *}\end{array}$ & $\begin{array}{c}-1.41 \\
(.059)^{* * *}\end{array}$ \\
\hline FICO & & $\begin{array}{c}.001 \\
(1.12 \mathrm{e}(-4))^{* * *}\end{array}$ & & & $\begin{array}{c}1.29 \mathrm{e}(-4) \\
(2.87 \mathrm{e}(-5))^{* * *}\end{array}$ & $\begin{array}{c}3.43 \mathrm{e}(-4) \\
(1.34 \mathrm{e}(-5))^{* * *}\end{array}$ & $\begin{array}{c}2.86 \mathrm{e}(-4) \\
(2.02 \mathrm{e}(-5))^{* * *}\end{array}$ \\
\hline Low/no documentation & & $\begin{array}{c}-.147 \\
(.013)^{* * *}\end{array}$ & & & $\begin{array}{c}.012 \\
(.005)^{* * *}\end{array}$ & $\begin{array}{c}-.044 \\
(.005)^{* * *}\end{array}$ & $\begin{array}{c}-.043 \\
(.005)^{* * *}\end{array}$ \\
\hline Low equity ratio & & & $\begin{array}{l}.017 \\
(.010)^{*}\end{array}$ & & & $\begin{array}{c}-.139 \\
(.012)^{* * *}\end{array}$ & $\begin{array}{c}-.146 \\
(.012)^{* * *}\end{array}$ \\
\hline Low-mid equity ratio & & & $\begin{array}{c}-.031 \\
(.011)^{* * *}\end{array}$ & & & $\begin{array}{c}-.208 \\
(.021)^{* * *}\end{array}$ & $\begin{array}{c}-.214 \\
(.022)^{* * *}\end{array}$ \\
\hline High-mid equity ratio & & & $\begin{array}{c}-.175 \\
(.008)^{* * *}\end{array}$ & & & $\begin{array}{c}-.425 \\
(.014)^{* * *}\end{array}$ & $\begin{array}{c}-.429 \\
(.014)^{* * *}\end{array}$ \\
\hline Low nonperforming loan ratio & & & $\begin{array}{c}.160 \\
(.013)^{* * *}\end{array}$ & & & $\begin{array}{c}.197 \\
(.023)^{* * *}\end{array}$ & $\begin{array}{c}.205 \\
(.023)^{* * *}\end{array}$ \\
\hline Low-mid nonperforming loan ratio & & & $\begin{array}{c}.160 \\
(.014)^{* * *}\end{array}$ & & & $\begin{array}{c}.167 \\
(.020)^{* * *}\end{array}$ & $\begin{array}{c}.176 \\
(.021)^{* * *}\end{array}$ \\
\hline High-mid nonperforming loan ratio & & & $\begin{array}{c}.197 \\
(.016)^{* * *}\end{array}$ & & & $\begin{array}{c}.285 \\
(.023)^{* * *}\end{array}$ & $\begin{array}{c}.292 \\
(.024)^{* * *}\end{array}$ \\
\hline Past 2yr house price apprec. & & & & $\begin{array}{l}.145 \\
(.106)\end{array}$ & & & $\begin{array}{c}-.297 \\
(.028)^{* * *}\end{array}$ \\
\hline Pseudo $R^{2}$ & .302 & .089 & .076 & .052 & .320 & .356 & .357 \\
\hline Observations & $1,643,082$ & $1,643,082$ & $1,643,082$ & $1,643,082$ & $1,643,082$ & $1,643,082$ & $1,643,082$ \\
\hline
\end{tabular}

All specifications include year-MSA interactions.

Coefficient estimates are marginal effects, at sample means.

Standard errors clustered by MSA.

Significant at: .01(***), .05(**),.1(*). 
Figure 3: Survivor functions by investor type

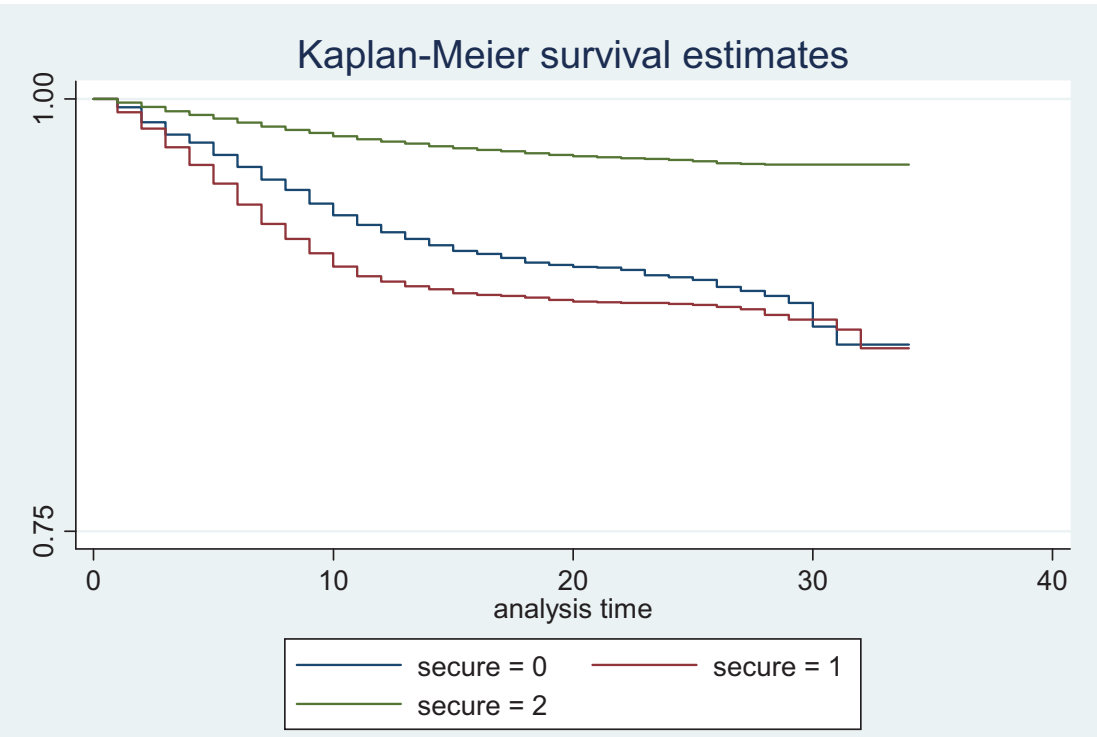

Retained: secure $=0$, private securitization: secure $=1$, GSE securitization: secure $=2$

Alternatively, a mortgage can terminate via a prepayment, either because the borrower is selling the house or because they are refinancing the mortgage. Mortgages that remain current at the end of the sample period are treated as censored observations. Once a terminating event has occurred, the mortgage history is complete. We do not follow loans that default and then cure at some time in the future.

The hazard rate for termination risk $j, h_{j}(t)$ is the probability that the borrower terminates the mortgage at time $T$ by termination type $j$, conditional on surviving to time $t$,

$$
h_{j}(t)=\lim _{\delta \rightarrow 0} \frac{\operatorname{Pr}(t<T \leq T+\delta, j \mid T \geq t)}{\delta} .
$$

In the literature it is common to assume a proportional hazard framework where the conditional hazard function is factored into a "baseline" hazard $h_{j}^{b}$ that is a function of $t$ alone, and a function $\phi\left(x, \beta_{j}\right)$ that incorporates explanatory variables related to the hazard of interest. That is, the covariates shift the relative risk of failure but they do not affect the underlying shape of the hazard function. Note that the parameter vector $\beta_{j}$ is indexed by $j$, reflecting the way that covariates are 
allowed to impact the two hazards (default and prepayment) in different ways. We assume that the function $\phi$ takes an exponential form so that the hazard is given by,

$$
h_{j}(t \mid x)=h_{j}^{b}(t) \exp \left(x \beta_{j}\right)
$$

This specification lends itself to a fairly straightforward interpretation of the effects of the covariates on the hazard rate. Consider two mortgage histories $\mathrm{A}$ and $\mathrm{B}$ with $x$ 's that differ only in that one history (history A) has a one unit increase in a single covariate $x_{s}$. In comparing the hazard functions of these two mortgage histories, the hazard ratio, $\frac{h_{j}\left(t \mid x^{A}\right)}{h_{j}\left(t \mid x^{B}\right)}$, takes the simple form $e^{\beta_{j s}}$. A hazard ratio greater than one (less than one) indicates an estimated increase (decrease) in termination probability associated with that particular covariate. ${ }^{11}$

In all of the specifications explored here, we construct a current LTV by applying the house price appreciation of the relevant zip code-level house price index from Zillow to the reported LTV at origination. For FRMs, the interest rate variable is time-varying, and equal to the difference between the fixed rate on the mortgage and the current 30-year rate as given by the Freddie Mac mortgage market survey. For ARMs the interest rate varies according to the contracted reset schedule. Thus, we construct our interest rate variable somewhat differently, by taking reported "ARM margin rate" which measures the spread the borrower must pay over and above the benchmark rate and adding to it the current one-year ARM rate reported Freddie Mac. We then take the difference between this sum and the current 30-year FRM. Thus, a decline in this variable reflects a flattening of the yield curve which would tend to induce borrowers to refinance out of ARMs and into FRMs. We also employ a set of static covariates, including those used in the securitization regressions in the previous section, additional controls for the documentation status of the mortgage, and indicators

\footnotetext{
${ }^{11}$ The canonical competing risks proportional hazards model is estimated by maximizing the partial likelihood function

$$
L(\beta)=\prod_{j=1}^{m} \prod_{i=1}^{k_{j}} \frac{\exp \left[x_{j i}\left(t_{j i}\right) \beta_{j}\right]}{\sum_{l \in R\left(t_{j i}\right)} \exp \left[x_{l}\left(t_{j i}\right) \beta_{j}\right]},
$$

where $i$ denotes a history, $j=1, . ., m$ denotes the types of termination, $k_{j}$ denotes the number of subjects in the data with termination type $j$, and $R\left(t_{j i}\right)$ denotes the set of observations exposed to risk $j$ after $t$ periods of history. The likelihood function is "partial" in the sense that the method produces consistent estimates of the $\beta$ s without a simultaneous estimation of the baseline hazard. See Cameron and Trivedi (2005) for details. We performed the maximization using routines written for Stata 11.
} 
for whether the ARM is an option ARM or an interest-only loan. We also include indicator variables for whether the initial LTV was exactly equal to $80 \%$. Given the large number of loans in our sample with exactly $80 \%$ LTV and the rapid rise in house prices in California and the rise in the jumbo loan share, it is certainly possible that some of these loans with $80 \%$ LTV actually understate true borrower leverage because of the existence of a second-lien mortgage that we do not observe. We also include a measure of local banking market competition, the deposit concentration in the market. Finally, we include the local house price appreciation over the past two years leading up to the loan origination as a way to control for markets which may have experienced a housing market bubble that proceeded to burst.

Since the estimation of competing risks models is resource-intensive, the results below reflect estimation on a 20 percent random sample of our data set. In all the hazard model tables we report hazard ratios with p-values in parentheses. The reported results are for the default hazard. We report the results for the prepayment hazard in the appendix. Since prepayment is a competing risk to default and since prepayment speeds can be quite different between borrowers with FRMs and ARMs, we estimate the hazard models separately for these types of borrowers. The main results are in Tables 5 and 6 .

The results generally conform with the unconditional results as well as our expectations about the role of risk factors. In terms of observable risk factors, the current LTV is a strong predictor of default. In all the specifications considered here, for both FRMs and ARMs, we see that a ten percentage point increase in current LTV raises the default hazard by about 30 percent. This is intuitive, of course; we would predict borrowers to be more inclined to default on their mortgages when their equity in their homes goes down. This could be due to strategic (rational) default, or could simply reflect the fact that homeowners who have suffered some sort of life event will have a more difficult time avoiding default if they cannot sell their houses for enough to repay their mortgages.

All borrowers with current mortgage rates that are high relative to current market rates are more likely to default. This could be because falling market rates in our sample are associated with bad economic times and an increased likelihood of suffering some kind of life event, like job loss or 
some other kind of income shock. Alternatively, in our competing risks framework, it is helpful to remember that borrowers are more likely to prepay their mortgages when their current mortgage rates are high relative to the market (see also the appendix for the estimates of the prepayment models). The positive relationship between the incentive to prepay and the default hazard suggests that there is some heterogeneity in borrowers that is observable to lenders but not to the empirical researcher. Apparently, borrowers are more likely to default when they have incentive to prepay, but were somehow prevented from exercising this option.

Other risk factors shift the hazard ratio in the expected manner. For example, borrowers with exactly $80 \%$ LTV at origination have higher default probabilities, consistent with the notion that these borrowers may have a second lien mortgage. The FICO score is negatively related to default, as expected. But there are important differences across FRMs and ARMs. For borrowers with FRMs, the subprime and low-documentation indicators are not significantly related to default. For ARMs, subprime borrowers have much higher default hazards than non-subprime borrowers, possibly because subprime borrowers are more vulnerable to income and employment shocks. Also, ARM borrowers with less-than-complete documentation on their loans default at a faster rate than borrowers that provided full documentation. This point seems intuitive as well; borrowers who do not disclose certain financial data to lenders and are therefore willing to pay higher loan rates are probably going to be different from borrowers who provide full documentation. However, it is curious that borrowers choosing FRMs and also choosing not to provide full documentation did not have significantly different default rates than the average FRM borrower.

The main variable of interest in the hazard model analysis, however, is the investor-type variable, which is equal to one if the loan was privately securitized. We also constructed a dummy variable indicating whether the mortgage was securitized by one of the GSEs. For FRMs, the private securitization variable is either insignificant or significant but with the unexpected sign (less likely to default than retained mortgages). Loans securitized with the GSEs have significantly lower default hazard rates, even after controlling for all the risk factors.

The best evidence for differential performance of privately securitized loans is for ARMs. ${ }^{12}$. In

\footnotetext{
${ }^{12}$ See also Elul $(2011)$ for a similar result
} 
most of the specifications in Table 6, the privately securitized ARMs are estimated to have default rates in the range of 13\%-16\% higher than otherwise identical loans. To put this in perspective, with an ARM default rate of $9.9 \%$ in our sample, privately securitized ARMs are estimated to have default rates about 1.3-1.6 percentage points higher than ARMs retained in the portfolio. Note that the hazard ratios for the GSE and privately securitized ARMs are significantly different than 1.0 in all specifications considered in table 6, so that investor type is estimated to be statistically significant for ARM loan performance even after controlling for our chosen risk factors. However, the maximized log (pseudo)likelihoods of the estimated models change little when including the investor type variables. For example, in the most naive specifications where default depends solely on current LTV, the LTV80 indicator, and the interest rate variable (column (i) of Table 6), the model log likelihood increases by less than .1 percent after including the investor type variables (column (ii) of Table 6). Indeed, observable risk factors such as current LTV and the subprime and documentation status are estimated to have a much much larger effect on the default hazard than investor type.

\section{Price Regressions}

While the results from the default rate analysis indicate that privately securitized loans-in particular ARMs-performed worse than retained loans with similar observable risk characteristics, this does not necessarily imply that lenders passed on loans they knew to be of low quality but investors did not or that the option to securitize undermines lender incentives to screen borrowers. If we assume that, ex ante, every mortgage has a positive probability of being retained, then we can use mortgage interest rates to help make this determination. Say, for example, that lenders know the borrower's payment-to-income ratio, but neither we nor investors do. Suppose, further, that lenders tend to securitize mortgages with high payment-to-income ratios and that the payment-to-income ratio is positively correlated with default. Then, given that, ex ante, for any mortgage, there is a chance that the lender will retain it, the loan rate on securitized loans should be higher than the loan rate on retained loans, controlling for risk characteristics that we can observe. If, on the other hand, conditional contract rates on securitized mortgages do not turn out to be higher than rates 
Table 5: Competing Risks Models: FRM Default Hazard

\begin{tabular}{|c|c|c|c|c|c|c|c|}
\hline & (i) & (ii) & (iii) & (iv) & $(\mathrm{v})$ & (vi) & (vii) \\
\hline Current LTV & $\begin{array}{l}1.027 \\
(.00)^{* * *}\end{array}$ & $\begin{array}{l}1.027 \\
(.00)^{* * *}\end{array}$ & $\begin{array}{l}1.027 \\
(.00)^{* * *}\end{array}$ & $\begin{array}{l}1.027 \\
(.00)^{* * *}\end{array}$ & $\begin{array}{l}1.024 \\
(.00)^{* * *}\end{array}$ & $\begin{array}{c}1.023 \\
(.00)^{* * *}\end{array}$ & $\begin{array}{c}1.024 \\
(.00)^{* * *}\end{array}$ \\
\hline LTV $80 \%$ at orig. & $\begin{array}{l}1.222 \\
(.00)^{* * *}\end{array}$ & $\begin{array}{c}1.224 \\
(.00)^{* * *}\end{array}$ & $\begin{array}{l}1.259 \\
(.00)^{* * *}\end{array}$ & $\begin{array}{l}1.257 \\
(.00)^{* * *}\end{array}$ & $\begin{array}{l}1.304 \\
(.00)^{* * *}\end{array}$ & $\begin{array}{c}1.305 \\
(.00)^{* * *}\end{array}$ & $\begin{array}{l}1.298 \\
(.00)^{* * *}\end{array}$ \\
\hline Rate differential & $\begin{array}{c}2.531 \\
(.00)^{* * *}\end{array}$ & $\begin{array}{c}2.527 \\
(.00)^{* * *}\end{array}$ & $\begin{array}{c}2.531 \\
(.00)^{* * *}\end{array}$ & $\begin{array}{c}2.506 \\
(.00)^{* * *}\end{array}$ & $\begin{array}{c}1.978 \\
(.00)^{* * *}\end{array}$ & $\begin{array}{c}1.981 \\
(.00)^{* * *}\end{array}$ & $\begin{array}{c}2.033 \\
(.00)^{* * *}\end{array}$ \\
\hline GSE & & $\begin{array}{l}.957 \\
(.60)\end{array}$ & & $\begin{array}{c}.824 \\
(.01)^{* * *}\end{array}$ & & $\begin{array}{c}.834 \\
(.00)^{* * *}\end{array}$ & $\begin{array}{c}.773 \\
(.00)^{* * *}\end{array}$ \\
\hline Priv. investor & & $\begin{array}{l}.953 \\
(.447)\end{array}$ & & $\begin{array}{l}1.026 \\
(.771)\end{array}$ & & $\begin{array}{c}.881 \\
(.01)^{* * *}\end{array}$ & $\begin{array}{c}.858 \\
(.00)^{* * *}\end{array}$ \\
\hline Jumbo & & & $\begin{array}{c}.715 \\
(.00)^{* * *}\end{array}$ & $\begin{array}{c}.619 \\
(.00)^{* * *}\end{array}$ & & & $\begin{array}{l}.861 \\
(.05)^{* *}\end{array}$ \\
\hline Subprime & & & & & $\begin{array}{l}1.142 \\
(.15)\end{array}$ & $\begin{array}{l}1.102 \\
(.33)\end{array}$ & $\begin{array}{l}.994 \\
(.95)\end{array}$ \\
\hline FICO Score & & & & & $\begin{array}{c}.986 \\
(.00)^{* * *}\end{array}$ & $\begin{array}{c}.986 \\
(.00)^{* * *}\end{array}$ & $\begin{array}{c}.986 \\
(.00)^{* * *}\end{array}$ \\
\hline Low-documentation & & & & & $\begin{array}{l}1.023 \\
(.58)\end{array}$ & $\begin{array}{l}1.031 \\
(.44)\end{array}$ & $\begin{array}{l}1.020 \\
(.62)\end{array}$ \\
\hline $\begin{array}{l}\text { Deposit market } \\
\text { concentration }\end{array}$ & & & & & & & $\begin{array}{l}1.000 \\
(.63)\end{array}$ \\
\hline $\begin{array}{l}\text { Past } 2 \text { yr House } \\
\text { price apprec. }\end{array}$ & & & & & & & $\begin{array}{c}1.533 \\
(.00)^{* * *}\end{array}$ \\
\hline Log pseudolikelihood & $-56,373$ & $-56,373$ & $-56,339$ & $-56,324$ & $-54,956$ & $-54,950$ & $-54,920$ \\
\hline Number of observations & $2,838,717$ & $2,838,717$ & $2,838,717$ & $2,838,717$ & $2,838,717$ & $2,838,717$ & $2,838,717$ \\
\hline Number subjects & 200,317 & 200,317 & 200,317 & 200,317 & 200,317 & 200,317 & 200,317 \\
\hline
\end{tabular}


Table 6: Competing Risks Models: ARM Default Hazard

\begin{tabular}{|c|c|c|c|c|c|c|c|}
\hline & (i) & (ii) & (iii) & (iv) & (v) & (vi) & (vii) \\
\hline Current LTV & $\begin{array}{c}1.031 \\
(.00)^{* * *}\end{array}$ & $\begin{array}{c}1.031 \\
(.00)^{* * *}\end{array}$ & $\begin{array}{c}1.031 \\
(.00)^{* * *}\end{array}$ & $\begin{array}{l}1.031 \\
(.00)^{* * *}\end{array}$ & $\begin{array}{c}1.031 \\
(.00)^{* * *}\end{array}$ & $\begin{array}{c}1.031 \\
(.00)^{* * *}\end{array}$ & $\begin{array}{l}1.030 \\
(.00)^{* * *}\end{array}$ \\
\hline Rate differential & $\begin{array}{c}1.854 \\
(.00)^{* * *}\end{array}$ & $\begin{array}{c}1.816 \\
(.00)^{* * *}\end{array}$ & $\begin{array}{c}1.863 \\
(.00)^{* * *}\end{array}$ & $\begin{array}{c}1.820 \\
(.00)^{* * *}\end{array}$ & $\begin{array}{c}1.538 \\
(.00)^{* * *}\end{array}$ & $\begin{array}{c}1.513 \\
(.00)^{* * *}\end{array}$ & $\begin{array}{c}1.512 \\
(.00)^{* * *}\end{array}$ \\
\hline GSE & & $\begin{array}{c}.903 \\
(.04)^{* *}\end{array}$ & & $\begin{array}{c}.829 \\
(.00)^{* * *}\end{array}$ & & $\begin{array}{l}.981 \\
(.68)\end{array}$ & $\begin{array}{l}.895 \\
(.06)^{*}\end{array}$ \\
\hline Priv. investor & & $\begin{array}{l}1.131 \\
(.00)^{* * *}\end{array}$ & & $\begin{array}{c}1.138 \\
(.00)^{* * *}\end{array}$ & & $\begin{array}{c}1.163 \\
(.00)^{* * *}\end{array}$ & $\begin{array}{c}1.156 \\
(.00)^{* * *}\end{array}$ \\
\hline $80 \%$ LTV at orig. & $\begin{array}{c}1.575 \\
(.00)^{* * *}\end{array}$ & $\begin{array}{l}1.558 \\
(.00)^{* * *}\end{array}$ & $\begin{array}{l}1.571 \\
(.00)^{* * *}\end{array}$ & $\begin{array}{c}1.550 \\
(.00)^{* * *}\end{array}$ & $\begin{array}{c}1.652 \\
(.00)^{* * *}\end{array}$ & $\begin{array}{c}1.639 \\
(.00)^{* * *}\end{array}$ & $\begin{array}{c}1.628 \\
(.00)^{* * *}\end{array}$ \\
\hline Jumbo & & & $\begin{array}{c}.904 \\
(.00)^{* * *}\end{array}$ & $\begin{array}{c}.863 \\
(.00)^{* * *}\end{array}$ & & & $\begin{array}{l}.920 \\
(.01)^{* *}\end{array}$ \\
\hline Subprime & & & & & $\begin{array}{c}1.295 \\
(.00)^{* * *}\end{array}$ & $\begin{array}{c}1.268 \\
(.00)^{* * *}\end{array}$ & $\begin{array}{c}1.260 \\
(.00)^{* * *}\end{array}$ \\
\hline FICO Score & & & & & $\begin{array}{c}.993 \\
(.00)^{* * *}\end{array}$ & $\begin{array}{c}.993 \\
(.00)^{* * *}\end{array}$ & $\begin{array}{c}.993 \\
(.00)^{* * *}\end{array}$ \\
\hline Low-documentation & & & & & $\begin{array}{c}1.268 \\
(.00)^{* * *}\end{array}$ & $\begin{array}{c}1.274 \\
(.00)^{* * *}\end{array}$ & $\begin{array}{c}1.273 \\
(.00)^{* * *}\end{array}$ \\
\hline $\begin{array}{l}\text { Deposit market } \\
\text { concentration }\end{array}$ & & & & & & & $\begin{array}{l}1.000 \\
(.65)\end{array}$ \\
\hline $\begin{array}{l}\text { Past } 2 \mathrm{yr} \text { House } \\
\text { price apprec. }\end{array}$ & & & & & & & $\begin{array}{l}1.085 \\
(.65)\end{array}$ \\
\hline Option ARM & & & $\begin{array}{c}1.261 \\
(.00)^{* * *}\end{array}$ & $\begin{array}{l}1.259 \\
(.00)^{* * *}\end{array}$ & & & $\begin{array}{c}1.165 \\
(.00)^{* * *}\end{array}$ \\
\hline Interest only & & & $\begin{array}{c}1.119 \\
(.00)^{* * *}\end{array}$ & $\begin{array}{l}1.146 \\
(.00)^{* * *}\end{array}$ & & & $\begin{array}{c}1.311 \\
(.00)^{* * *}\end{array}$ \\
\hline Log pseudolikelihood & $-128,501$ & $-128,474$ & $-128,432$ & $-128,391$ & $-127,715$ & $-127,689$ & $-127,613$ \\
\hline Number of observations & $1,243,210$ & $1,243,210$ & $1,243,210$ & $1,243,210$ & $1,243,210$ & $1,243,210$ & $1,243,210$ \\
\hline Number subjects & 125,938 & 125,938 & 125,938 & 125,938 & 125,938 & 125,938 & 125,938 \\
\hline
\end{tabular}

Significance: $.01(* * *), .05(* *), .1\left(^{*}\right)$. 
on retained mortgages, then we might doubt that lenders knowingly exploited private information or deliberately failed to thoroughly screen borrowers whose loans were likely to be securitized.

Admittedly, this investigation is not easy to implement given the complexity of the mortgage pricing problem. The risk of a mortgage loan depends not just on credit factors, but also on the likelihood that borrowers will prepay the loan early through a refinancing. We take a number of steps to attempt to control for differences in refinancing propensity. We include only loans with a thirty-year term. We consider FRMs and ARMs separately, given the different prepayment speeds on these loans and the likely effect this will have on loan pricing. We also include indicators for loans with balloon payments, the number of months until the scheduled balloon payment, and a variable indicating if the loan has a prepayment penalty.

Our loan price measure is the spread of the contract rate on the loan over a benchmark interest rate. This measure is straightforward to construct for FRMs. Given our sole focus on 30-year mortgages, the spread is the loan rate less the average yield on the 10-year constant maturity Treasury note in the quarter of the origination. For ARMs, the pricing is more complicated. We use the margin rate on the loan, which is literally the spread between the loan rate at the time of an interest rate reset and the stated benchmark. ${ }^{13}$

We test for an effect of securitization on loan prices in two different ways. In the first, we run a simple OLS regression of the spread of mortgage $i$ originated in year $t$ on our complete set of risk factors $X$,

$$
s p r_{i t}=a+b X_{i t}+e_{i t} .
$$

Here, the set of risk proxies in $X$ include the securitization indicator as well as many of the same variables used throughout the empirical analysis: jumbo loan status, LTV at origination, credit score, documentation status, a subprime loan indicator, and market-specific control variables such as the MSA-level deposit concentration measure and the past two years of house price appreciation. For ARMs, we also include an indicator for option ARMs and for the benchmark loan rate that

\footnotetext{
${ }^{13}$ Note that unlike the FRM spread, the spread on an ARM may be relative to a rate that is not risk free (e.g., LIBOR). Recall that we used the same margin rate in our construction of the current mortgage rate variable that went into the default risk modeling
} 
the ARM rate is tied to. Finally, for the OLS regressions, we include a set of year-MSA interaction terms.

The second empirical approach attempts to control for possible endogeneity between loan pricing spreads and securitization for reasons other than risk. For example, if the securitization decision is at least partially driven by regulatory capital requirement considerations, then the existence of a capital charge for retained mortgages would tend to drive up loan rates on these mortgages. To address this type of endogeneity, we adopt the approach in Maddala (1983) for estimating simultaneous equation models with both continuous and limited dependent endogenous variables. We implement the model as in Keshk (2003). The first equation in the system is the linear model of the loan spreads discussed above, minus the investor type indicator as an explanatory variable. The second equation in the system is a probit model of securitization,

$$
\operatorname{Pr}\left(y_{i t}=1\right)=F\left(X_{i t}, Z_{i t} ; \theta\right)
$$

where $y$ is an 0-1 variable indicating whether the loan was privately securitized or not, $F$ is the standard normal cumulative distribution function, and $\theta$ is a vector of parameters. The variables in $X$ are the same risk factors from the spread regression above (less the securitization indicator, of course). The variables in the matrix $Z$ are instruments that consist of both MSA-specific and bankspecific variables. The MSA-specific variables are the average ROA, equity capital-to-assets ratio, and asset size of the banks with loans in the MSA and the mortgage loan concentration measure for the MSA in that year. We also use bank-specific instruments consisting of the same equity capital-to-asset ratio and nonperforming loan ratio category variables we used in the securitization regressions in Section, as well as a variable indicating whether the bank has a branch in the MSA in which the property is located.

For these instruments to be valid, we are effectively assuming that they affect the propensity of lenders to securitize, but do not affect loan pricing. For example, a bank may choose to securitize a loan or not based on its current capital ratio, but local market conditions demand that the loan price charged by the bank is not affected by the capital ratio of the lender. Both models are estimated in a first stage using all the exogenous data. Then the predicted values from each model are included 
in a second stage. Below we report the coefficients from the second stage OLS regressions under the (IV) columns.

We look for differences in loan rates in three different ways. First, we compare all securitized loans to retained loans (Table 7). Second, we compare loans securitized through the GSEs to all other loans (Table 8). This second set of regressions is motivated by the argument that privately securitized loans and retained loans are more similar to each other in terms of ex-ante risk factors than they are to the loans sent to the GSEs. Finally, we restrict the sample to only privatelysecuritized loans or loans retained by the banks (Table 9).

On balance, we see many of the same qualitative results in the pricing regressions as we saw in the default analysis. Virtually all of the risk factors have the expected signs: higher LTVs, lower FICO scores, low documenation, and subprime status all result in higher loan spreads at origination. One of the most interesting things about these sets of regressions is to compare how loan pricing changes across the FRMs and the ARMs. For a variable such as LTV, which we found to be extremely important for explaining defaults, for most of our sample there is little difference across FRMs and ARMs in the way that higher LTVs impact the loan rate (see Tables 7 and 8). For example, in Table 7 we see that under the OLS estimates, lenders required an estimated 22 basis points for an extra percentage point of LTV for both FRMs and ARMs. Since we have MSA-level variables in our regression that should proxy for expectations about future local economic conditions, this result seems to indicate that lenders did not perceive large differences in the propensity to default across FRM and ARM borrowers. When we drop the mortgages securitized by the GSEs, however, fairly large differences emerge (Table 9). In this riskier subsample, it appears that lenders charged significantly more for an extra percentage point of LTV when offering a FRM compared to an ARM.

There are also large differences between the pricing of FRMs and ARMs that are labeled as subprime. The subprime label, of course, is a summary measure that embeds a great deal of information about borrower and loan characteristics, some of which the econometrician does not observe. It is difficult to make "holding all other factors constant" statements when varying the subprime measure. However, in the subsample containing only privately securitized and retained 
Table 7: Loan price regressions

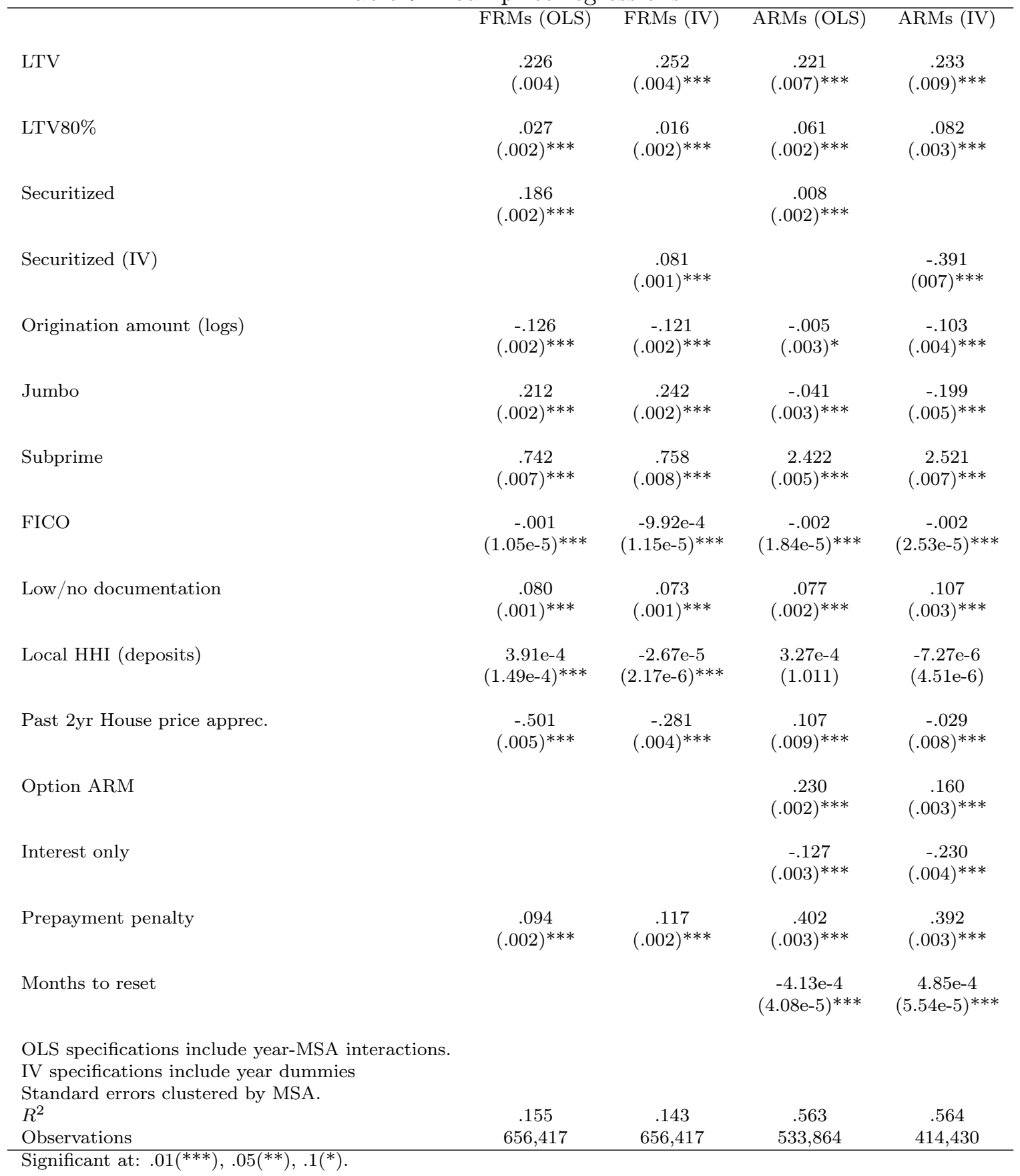


Table 8: Loan price regressions: GSE securitizations

\begin{tabular}{|c|c|c|c|c|}
\hline . & FRMs (OLS) & FRMs (IV) & ARMs (OLS) & ARMs (IV) \\
\hline LTV & $\begin{array}{c}.215 \\
(.004)^{* * *}\end{array}$ & $\begin{array}{c}.252 \\
(.004)^{* * *}\end{array}$ & $\begin{array}{c}.221 \\
(.007)^{* * *}\end{array}$ & $\begin{array}{c}.214 \\
(.026)^{* * *}\end{array}$ \\
\hline LTV $80 \%$ & $\begin{array}{c}.031 \\
(.002)^{* * *}\end{array}$ & $\begin{array}{c}.016 \\
(.002)^{* * *}\end{array}$ & $\begin{array}{c}.061 \\
(.002)^{* * *}\end{array}$ & $\begin{array}{c}.139 \\
(.009)^{* * *}\end{array}$ \\
\hline GSE & $\begin{array}{c}.057 \\
(.002)^{* * *}\end{array}$ & & $\begin{array}{c}.008 \\
(.002)^{* * *}\end{array}$ & \\
\hline GSE (IV) & & $\begin{array}{c}.053 \\
(.003)^{* * *}\end{array}$ & & $\begin{array}{c}.604 \\
(021)^{* * *}\end{array}$ \\
\hline Origination amount (logs) & $\begin{array}{c}-.125 \\
(.002)^{* * *}\end{array}$ & $\begin{array}{c}-.121 \\
(.002)^{* * *}\end{array}$ & $\begin{array}{l}-.005 \\
(.003)^{*}\end{array}$ & $\begin{array}{c}.134 \\
(.011)^{* * *}\end{array}$ \\
\hline Jumbo & $\begin{array}{c}.239 \\
(.002)^{* * *}\end{array}$ & $\begin{array}{c}.335 \\
(.008)^{* * *}\end{array}$ & $\begin{array}{c}-.041 \\
(.003)^{* * *}\end{array}$ & $\begin{array}{c}1.525 \\
(.055)^{* * *}\end{array}$ \\
\hline Subprime & $\begin{array}{c}.767 \\
(.007)^{* * *}\end{array}$ & $\begin{array}{c}.885 \\
(.011)^{* * *}\end{array}$ & $\begin{array}{c}2.422 \\
(.005)^{* * *}\end{array}$ & $\begin{array}{c}4.074 \\
(.100)^{* * *}\end{array}$ \\
\hline FICO & $\begin{array}{c}-.001 \\
(1.05 \mathrm{e}-5)^{* * *}\end{array}$ & $\begin{array}{c}-.001 \\
(1.08 \mathrm{e}-5)^{* * *}\end{array}$ & $\begin{array}{c}-.002 \\
(1.84 \mathrm{e}-5)^{* * *}\end{array}$ & $\begin{array}{c}-.003 \\
(7.36 \mathrm{e}-5)^{* * *}\end{array}$ \\
\hline Low/no documentation & $\begin{array}{c}.088 \\
(.001)^{* * *}\end{array}$ & $\begin{array}{c}.093 \\
(.001)^{* * *}\end{array}$ & $\begin{array}{c}.077 \\
(.002)^{* * *}\end{array}$ & $\begin{array}{c}.122 \\
(.007)^{* * *}\end{array}$ \\
\hline Local HHI (deposits) & $\begin{array}{c}4.04 \mathrm{e}-4 \\
(1.49 \mathrm{e}-4)^{* * *}\end{array}$ & $\begin{array}{c}-3.12 \mathrm{e}-5 \\
(2.04 \mathrm{e}-6)^{* * *}\end{array}$ & $\begin{array}{l}3.27 \mathrm{e}-4 \\
(1.011)\end{array}$ & $\begin{array}{c}8.16 \mathrm{e}-5 \\
(1.31 \mathrm{e}-5)^{* * *}\end{array}$ \\
\hline Past 2yr House price apprec. & $\begin{array}{c}-.502 \\
(.005)^{* * *}\end{array}$ & $\begin{array}{c}-.248 \\
(.004)^{* * *}\end{array}$ & $\begin{array}{c}.107 \\
(.009)^{* * *}\end{array}$ & $\begin{array}{c}.238 \\
(.024)^{* * *}\end{array}$ \\
\hline Option ARM & & & $\begin{array}{c}.230 \\
(.002)^{* * *}\end{array}$ & $\begin{array}{c}.210 \\
(.009)^{* * *}\end{array}$ \\
\hline Interest only & & & $\begin{array}{c}-.127 \\
(.003)^{* * *}\end{array}$ & $\begin{array}{c}.060 \\
(.012)^{* * *}\end{array}$ \\
\hline Prepayment penalty & $\begin{array}{c}.094 \\
(.002)^{* * *}\end{array}$ & $\begin{array}{c}.120 \\
(.002)^{* * *}\end{array}$ & $\begin{array}{c}.402 \\
(.003)^{* * *}\end{array}$ & $\begin{array}{c}1.112 \\
(.026)^{* * *}\end{array}$ \\
\hline Months to reset & & & $\begin{array}{c}-4.13 \mathrm{e}-4 \\
(4.08 \mathrm{e}-5)^{* * *}\end{array}$ & $\begin{array}{c}-.008 \\
(2.98 \mathrm{e}-4)^{* * *}\end{array}$ \\
\hline $\begin{array}{l}\text { OLS specifications include year-MSA interactions. } \\
\text { IV specifications include year dummies } \\
\text { Standard errors clustered by MSA. }\end{array}$ & & & & \\
\hline $\begin{array}{l}R^{2} \\
\text { Observations }\end{array}$ & $\begin{array}{c}.148 \\
656,417\end{array}$ & $\begin{array}{c}.137 \\
656,417\end{array}$ & $\begin{array}{c}.569 \\
533,864\end{array}$ & $\begin{array}{c}.564 \\
414,430\end{array}$ \\
\hline
\end{tabular}


Table 9: Loan price regressions: retained and private-securitizations only

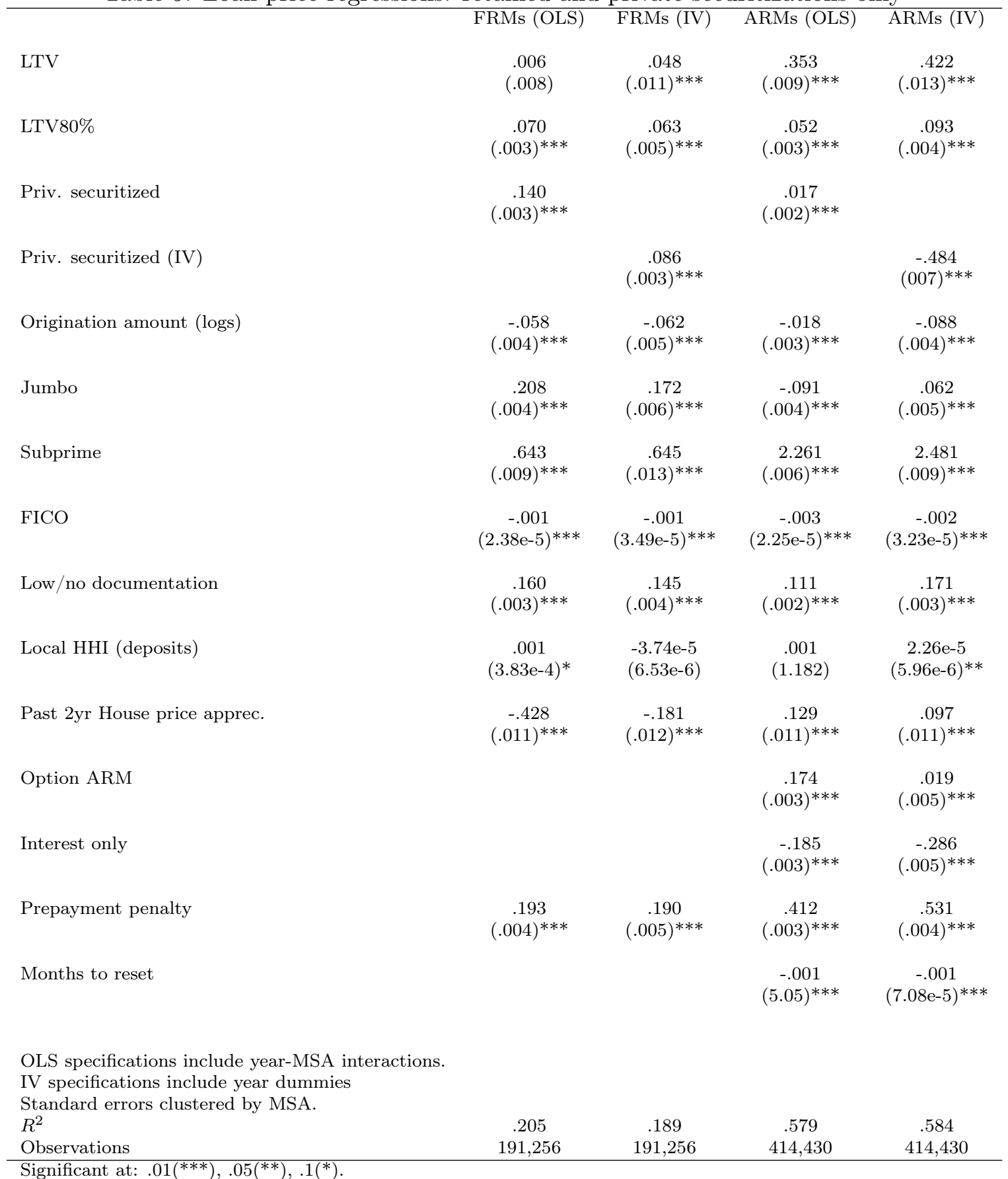


mortgages, it is striking how much more sensitive the loan pricing is for ARMs than for FRMs. Evidently, lenders perceived there to be large differences in the risk of subprime borrowers who selected FRMs versus ARMs.

Regarding the securitization variable, the results from the pricing regressions indicate that the coefficient on securitization is statistically significant and positive for FRMs, and significant and negative for ARMs. The loan rate spreads in the analysis are recorded as percentage points. Thus, in the IV regressions (panel (ii) for FRMs and panel (iv) for ARMs) of Table 9 privately securitized mortgage loans commanded spreads that were on average about 8 basis points higher than retained FRMs and nearly 50 basis points lower for ARMs, respectively.

The positive correlation between securitization and the loan spread for FRMs, even in the presence of our risk factors and control variables, suggests that there may have been some risk factors that were positively correlated with securitization probability that lenders were aware of, but investors were not and for which we cannot control. However, this result still leaves open the possibility that investors themselves may have received, even if by happenstance, a fair return on their securities. We cannot know from this analysis whether that was true. Such a question can only be examined with the aid of a fully specified asset pricing model. But the fact that we found no meaningful differences in default rates for securitized FRMs would seem to point against confident claims that securitization exacerbated agency conflicts between lenders and investors for FRMs. For ARMs, the lower rates for securitized mortgages also point against claims of agency conflicts in connection with securitization.

\section{Conclusion}

We use a large loan-level data set of California mortgages to explore the factors behind the choices lenders made for funding residential mortgages during the U.S. housing boom in the 2000s. During the sample period under consideration, lenders appear to have securitized loans through privatelabel transactions that were in many ways observably riskier than the loans they retained in their portfolios. Thus, the results appear to be consistent with a story that lenders securitize loans in part to shed risks that are costly to hold on their balance sheets. 
Given the finding that private-label securitization are associated with the funding of riskier mortgages, and given the disastrous loan performance of California mortgages towards the end of the 2000s, one obvious question is whether the growth of private-label securitization somehow eroded underwriting standards, perhaps by exacerbating the many potential agency problems endemic to mortgage loan production. After controlling for observable risk factors and for prepayment risk, our work generally supports the notion that the most important indicators of mortgage default remain the set of classic risk factors such as LTV at origination, adverse changes in house prices, and the collection of attributes that result in borrowers being given the subprime classification. We do find some evidence that privately securitized ARMs had higher default rates than retained ARMs, but that these differences are not due to privately observed risk factors that would be captured in loan rates. Indeed, we find that after controlling for endogeneity in the loan pricing and securitization choice, rates on securitized ARMs were actually lower than for retained ARMs.

\section{References}

Ambrose, B. W., M. LaCour-Little, and A. B. Sanders (2003): "Does Regulatory Capital Arbitrage or Asymmetric Information Drive Securitization?," Unpublished Manuscript.

Ashcraft, A. B., and T. Schuermann (2008): "Understanding the Securitization of Subprime Mortgage Credit," Federal Reserve Bank of New York Staff Reports, (318).

Cameron, A. C., and P. K. Trivedi (2005): Microeconometrics: Methods and Applications. Cambridge University Press.

Carey, M. (1998): "Credit Risk in Private Debt Portfolios," Journal of Finance, 53(4), 1363-1387.

Dionne, G., and T. M. Harchaoui (2003): "Banks' Capital, Securitization and Credit Risk: An Empirical Evidence for Canada," working paper, HEC Working Paper No. 03-01.

Elul, R. (2011): "Securitization and Mortgage Default," Federal Reserve Bank of Philadelphia working paper. 
Jones, D. (2004): "Emerging problems with the Basel Capital Accord: Regulatory capital arbitrage and related issues," Journal of Banking and Finance, 24, 35-58.

Karaoglu, N. E. (2005): "Regulatory Capital and Earnings Management in Banks: The Case of Loan Sales and Securitizations," working paper 2005-05, FDIC Center for Financial Research.

Keshk, O. M. G. (2003): "CDSIMEQ: A Program to Implement Two-Stage Probit Least Squares," The Stata Journal, 3(2), 1-11.

Keys, B. J., T. K. Mukherjee, A. Seru, and V. Vig (2010): "Did Securitization Lead to Lax Screening? Evidence from Subprime Loans," Forthcoming in Quarterly Journal of Economics, $125(1)$.

Maddala, G. S. (1983): Limited-Dependent and Qualitative Variables in Econometrics. Cambridge University Press.

Minton, B., A. Sanders, and P. E. Strahan (2004): "Securitization by Banks and Finance Companies: Efficient Financial Contracting or Regulatory Arbitrage?," Ohio State University Working Paper No. 2004-25.

Nolan, A. (2005): "Sweet Basel II: The Regulatory Capital Treatment of Securitization and Credit Derivatives Activities of Banking Institutions," Goodwin Proctor LLP.

Pavel, C., And D. Phillis (1987): "Why Commercial Banks Sell Loans: An Empirical Analysis," Economic Perspectives, pp. 3-14. 
Table 10: Competing Risks Models: Prepayment Hazard

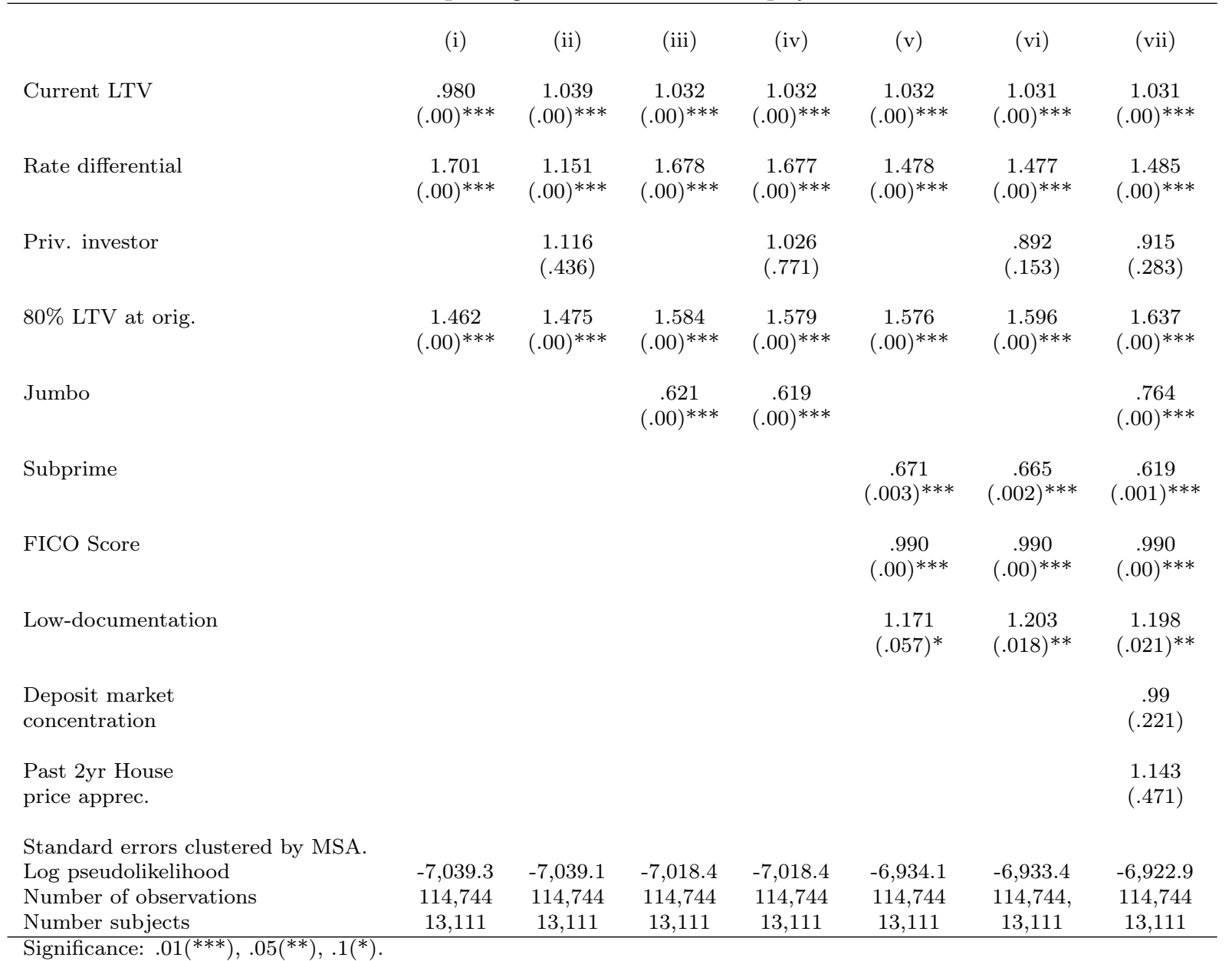


Table 11: Competing Risks Models: FRM Prepayment Hazard

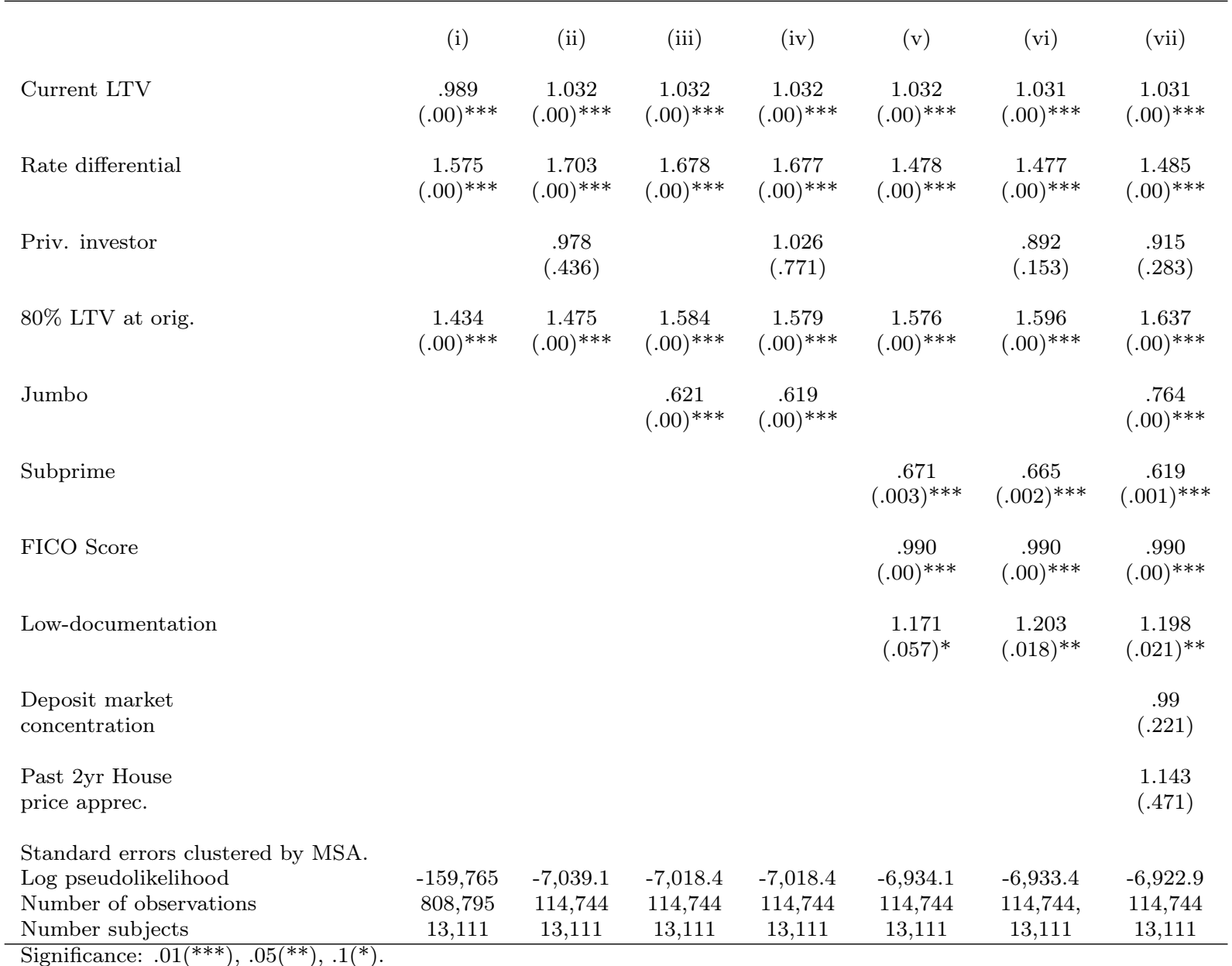


Table 12: Competing Risks Models: ARM Prepayment Hazard

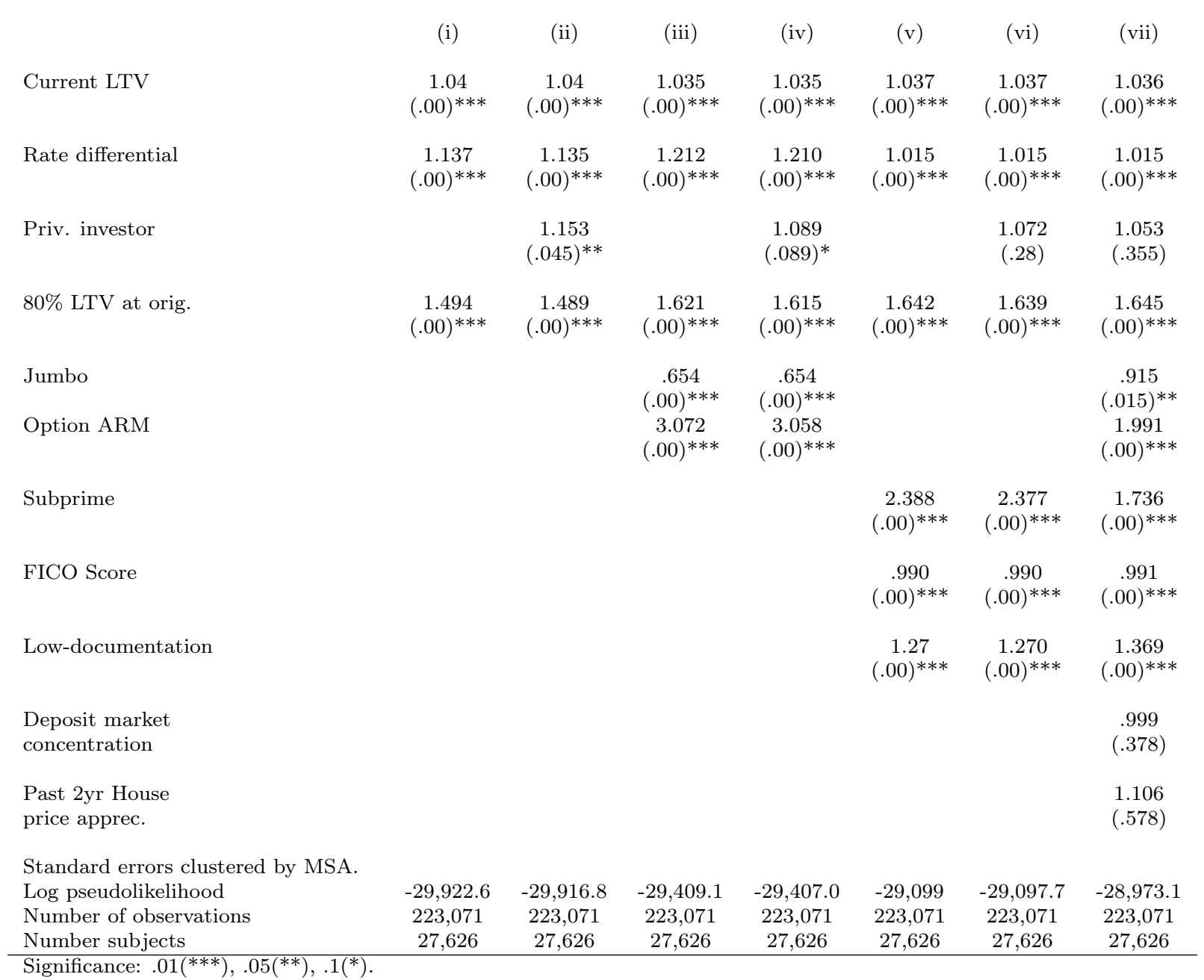

